\title{
SUCCINYLCHOLINE INDUCED HYPERKALAEMIA IN PATIENTS WITH STRABISMUS
}

\author{
Paul E. Berkebile, M.D., Hugo H. Pfaeffle, M.D., and R. Brian Smith, M.D. *
}

Dangerous hyperkalaemia has been reported following administration of succinylcholine chloride (SCC) to patients with burns, ${ }^{1,2}$ massive trauma ${ }^{3}$ tetanus, ${ }^{4}$ and a variety of neuromuscular disorders. ${ }^{5,6,7}$

Recently, Tammisto, et al., ${ }^{8}$ reported increases in blood levels of creatine phosphokinase (CPK) following administration of succinylcholine in patients with strabismus and found them to be higher than after administration to patients for dental and plastic operations. The CPK levels at 24 to 28 hours following succinylcholine administration in the strabismus patients were four times higher than those measured in the other patients. The hypothesis was presented - "that strabismus may sometimes be a sign of a latent general disturbance of the muscular system ...". Serum potassium levels were not determined.

This present study was undertaken to measure potassium levels following administration of succinylcholine to patients with strabismus to determine if dangerous hyperkalaemia does occur.

\section{METHOD}

Twenty patients were studied. Children received pentobarbitone $4 \mathrm{mg} / \mathrm{kg}$ and atropine, $0.02 \mathrm{mg} / \mathrm{kg}$ to $40 \mathrm{~kg}$ body weight. Adults received pentobarbitone 2.0 $\mathrm{mg} / \mathrm{kg}$ and atropine, $0.4-0.8 \mathrm{mg}$ according to body weight. Administration was by the intramuscular route 45 minutes before operation. Induction of anaesthesia was with nitrous oxide-halothane using a semi-closed circle absorption system for adults and a modified Jackson-Rees system for children under $30 \mathrm{~kg}$ weight. An intravenous infusion was started in the antecubital fossa of the left arm using an 18-gauge catheter. Five per cent dextrose in 0.2 per cent saline solution was administered.

Seven patients were given intravenous succinylcholine $1 \mathrm{mg} / \mathrm{kg}$ on a random selection basis to facilitate intubation after induction with halothane-nitrous oxide. The tracheae of the remaining 13 patients were intubated under halothane-nitrous oxide anaesthesia without succinylcholine. Lidocaine 2 per cent, $2.0 \mathrm{mg} / \mathrm{kg}$ was used for topical analgesia to the larynx. Cardiovascular parameters were monitored with a precordial stethoscope, blood pressure cuff and cardioscope. Venous blood samples were withdrawn prior to administration of succinylcholine and then at intervals of 2,5,7 and 10 minutes following its injection. Blood samples were taken

"Department of Anesthesiology, University of Pittsburgh School of Medicine.

Please direct all correspondence, to: R. Brian Smith, M.D., Director, Department of Anesthesiology, Eye and Ear Hospital, 230 Lothrop Street, Pittsburgh, Pennsylvania 15213.

Canad. Anaesth. Soc. J., vol. 20, no. 2, March 1973 
TABLE I

Serum Potassium (mEq/L) in Patients With Strabismus

\begin{tabular}{|c|c|c|c|c|c|c|c|}
\hline & & Pre & $2 \mathrm{~min}$. & $5 \mathrm{~min}$. & $7 \mathrm{~min}$. & $10 \mathrm{~min}$. & $\begin{array}{l}\text { Maximum } \\
\text { change }\end{array}$ \\
\hline \multirow{2}{*}{$\begin{array}{l}\text { Control } \\
\text { (without S.C.C.) }\end{array}$} & \multirow{2}{*}{$\begin{array}{l}\text { Mean } \\
\text { Standard error } \\
\text { of mean }\end{array}$} & 4.14 & 4.21 & 4.20 & 4.15 & 4.16 & +0.075 \\
\hline & & 0.06 & 0.05 & 0.06 & 0.05 & 0.05 & 0.08 \\
\hline \multirow{2}{*}{$\begin{array}{l}\text { Test } \\
\text { (with S.C.C.) }\end{array}$} & Mean & 4.61 & 4.88 & 4.93 & 4.85 & 4.82 & +0.37 \\
\hline & of mean & 0.13 & 0.13 & 0.16 & 0.15 & 0.16 & 0.05 \\
\hline
\end{tabular}

at similar intervals following intubation from the control group who had not received succinylcholine.

\section{Results}

The results are listed in Table I. The mean initial potassium value for the control group was $4.14 \mathrm{mEq} / 1$. The largest increase observed in this group was $0.55 \mathrm{mEq} / 1$. The mean potassium value at any sample after the initial was not significantly different (using the Test of Proportions with Yates Correction) from the initial mean value of this group. The mean maximum change for the group was $0.075 \mathrm{mEq} / 1$ and was not statistically significant.

In the seven patients who had received succinylcholine the mean initial potassium value was $4.61 \mathrm{mEq} / 1$. The maximum change observed in this group was $+0.65 \mathrm{mEq} / 1$. The mean maximum change in this group was small, being +0.37 $\mathrm{mEq} / 1$, but was statistically significant $(\mathrm{p}<0.01)$. The mean change at each sampling was small but statistically significantly different from the initial value.

\section{Discussion}

Paton ${ }^{9}$ measured changes in serum potassium levels following the administration of succinylcholine to a series of patients undergoing dental extractions under sodium thiopentone anaesthesia. Succinylcholine produced a small but significant rise in serum potassium. Similar changes in potassium were seen by Evers et al., ${ }^{10}$ in a series of patients undergoing elective gynaecological operations.

In the study by Tammisto et al., ${ }^{8}$ the CPK activity of 32 children undergoing dental extractions and minor plastic operations was compared with 34 patients operated on for strabismus. Repeated doses of succinylcholine were used intravenously. Halothane-nitrous oxide anaesthesia was used. They found an increase in CPK activity which was similar both after dental and plastic operations, but only one-quarter of that measured in the strabismus series. They did not measure serum potassium levels.

There was no evidence in our study that the increase of serum potassium levels in patients with strabismus receiving succinylcholine was different from that reported in other patients. In fact the changes here would seem to be less than those reported by Evers. ${ }^{10}$ 


\section{CoNCLUSION}

This study fails to reveal evidence that single intravenous doses of succinylcholine caused dangerous hyperkalaemia in patients undergoing anaesthesia for surgical correction of strabismus.

\section{RÉSUMÉ}

Chez 20 malades soumis à la chirurgie pour correction de strabisme, nous avons mesuré les taux de potassium sérique. Chez sept malades, après induction au protoxide d'azote/halothane, nous avons donné du chlorure de succinylcholine. Les treize autres malades ont été intubés sous anesthésie au protoxide d'azote/halothane seulement. Nous avons observé une légère mais significative élévation du potassium sérique chez les malades du groupe qui avait reçu de la succinylcholine alors que nous n'avons pas observé de changement chez les malades de l'autre groupe. Les auteurs en viennent à la conclusion qu'une seule dose de succinylcholine par voie endoveineuse, selon toute évidence, n'entraine pas chez les porteurs de strabisme, une hyperkalémie dangereuse.

\section{REFERENCES}

1. Allan, C.M., Cullen, W.G., \& Gillies, D.M. Ventricular fibrillation in a burned boy. Canad. Med. Assoc. J. 85: 432 (1961).

2. Tolmie, J.D., Joyce, T.H., \& Mrtchell, G.D. Succinylcholine danger in the burned patient. Anesthesiology 28: 467 (1967).

3. Mazze, R.I., Escue, H.M., \& Houston, J.B. Hyperkalemia and cardiovascular collapse following administration of succinylcholine in the traumatized patient. Anesthesiology 31 : 540 (1969).

4. Roth, F. \& WUtнuсн, H. The clinical importance of hyperkalaemia following suxamethonium administration. Brit. J. Anaesth. 41: 311 (1969).

5. Stone, W.A., Beach, T.P., \& Hamei.berg, W. Succinylcholine-danger in the spinal-cordinjured patient. Anesthesiology 32: 168 (1970).

6. ToвEY, R.E. Paraplegia, succinylcholine and cardiac arrest. Anesthesiology 32: 359 (1970).

7. Sмrтh, R.B. Hyperkalaemia following succinylcholine administration in neurological disorders: a review. Canad. Anaesth. Soc. J. 18, 2: 199 (1971).

8. Tammisto, T., Brander, P., Airaksinen, M.M., Tommila, V., \& Listola, J. Strabismus as a possible sign of latent muscular disease predisposing to suxamethonium-induced muscular injury. Annals of Clinical Research 2: 126-130 (1970).

9. Paton, W.D.M. The effects of muscle relaxants other than muscle relaxation. Anesthesiology 20: 432 (1959).

10. Evers, W., RAcz, G.B., \& DoBKin, A.B. A study of plasma potassium and electrocardiographic changes after a single dose of succinylcholine. Canad. Anaesth. Soc. J. 16: 273 (1969). 